Research article

\title{
The pros and cons of the invasive freshwater apex predator, European catfish Silurus glanis, and powerful angling technique for its population control
}

\author{
Lukáš Vejř́ik ${ }^{\mathrm{a}, \mathrm{b}, *}$, Ivana Vejř́íkováa ${ }^{\mathrm{a}}$, Luboš Kočvara ${ }^{\mathrm{a}}$, Petr Blabolil ${ }^{\mathrm{a}}$, Jiří Peterka ${ }^{\mathrm{a}}$, \\ Zuzana Sajdlováa, Tomáš Jůza ${ }^{a}$, Marek Šmejkal ${ }^{a}$, Tomáš Kolař́k ${ }^{a}$, Daniel Bartoň ${ }^{a}$, Jan Kubečka ${ }^{a}$, \\ Martin Čech ${ }^{\mathrm{a}}$ \\ ${ }^{a}$ Biology Centre of the Czech Academy of Sciences, Institute of Hydrobiology, Na Sádkách 7, 37005, České Budějovice, Czech Republic \\ ${ }^{\mathrm{b}}$ University of South Bohemia in České Budějovice, Faculty of Science, Branišovská 31, 37005, České Budějovice, Czech Republic
}

\section{A R T I C L E I N F O}

\section{Keywords:}

Apex consumer

Biomanipulation

Economic impact

Freshwater ecosystem

Hook-line

\begin{abstract}
A B S T R A C T
Catfish have spread across Europe and several countries out of this region within the last decades. Basic knowledge of this apex predator has revealed concerns of invasive behaviour and questions regarding its utilization as a biomanipulation species. However, a method enabling its regulation to a required level has not yet been developed. We simulated the impact of angling on the catfish population by method of hook-lines in two post-mining lakes with a monitored population consisting of tagged individuals and in two reservoirs as reference sites. Further, the efficiency of hook-lines as a reducing device was examined and the economic aspects were determined. Catfish population in localities where the species is unwanted or invasive may be efficiently reduced to a harmless level by hook-lines and angling (depending on the approach of anglers). The most efficient time of the year seems to be spring to early summer with catch efficiency of 5.4 individuals per 10 baits in one day. The catch efficiency markedly decreased during the second part of the year and did not exceed 2.8 individuals per 10 baits in one day. Mean size of catfish had negative impact whereas catfish biomass had positive impact on the catch efficiency. Trophic status and number of catfish in the locality had no impact on the catch efficiency. According to model, 11-18 bait-days per 1 ha per season is efficient to decrease catfish population to $10 \%$ of the original size. Both angling and hook-lines are very simple, they are financially and time bearable mechanisms of catfish regulation in any condition. However, catfish play an important role as a biomanipulative species in many localities. In this case where catfish is beneficial, angling presents a real threat of population collapse and loss of the biomanipulative effect.
\end{abstract}

\section{Introduction}

Angling fundamentally affects aquatic ecosystems, particularly the composition of the fish community, including its size and structure, drivers of evolution, overall changes in biota and water quality (Lewin et al., 2006; Laugen et al., 2014). Similarly, fisheries-related activities such as stocking of hatchery-reared fish or fish introductions may radically change a fish community, other organisms and ultimately entire aquatic ecosystems (Pauly, 1995; Robinson and Frid, 2003; Allan et al., 2005; Frank et al., 2005; Mullon et al., 2005). Commercially important fish species are for the most part affected by commercial fishing (Jørgensen et al., 2007), whereas populations of apex predators are also considerably affected by angling (Hunt, 2005; Lewin et al., 2006; Last et al., 2011). Pressure produced by a recreational activity may effectively lead to the disappearance of several species (Post et al., 2002; Hunt, 2005) and destabilisation of the ecosystem by changes to trophic cascades and trait-mediated effects (Arlinghaus et al., 2002; Myers et al., 2007). However, only limited information dealing with the impact of angling is known, particularly in freshwaters (Lewin et al., 2006).

Apex predators play a key role in driving the aquatic ecosystem. They affect the entire food web due to their generalism (Sinclar et al., 2003; Vejŕík et al., 2017a, 2017b). All parts of the food web are directly or indirectly affected by the presence of apex predators, including mesopredators (Prugh et al., 2009; Ripple et al., 2014). Lately, numbers of apex predators are generally decreasing and thus people have

\footnotetext{
${ }^{*}$ Corresponding author. Biology Centre of the Czech Academy of Sciences, Institute of Hydrobiology, Na Sádkách 7, 37005, České Budějovice, Czech Republic.

E-mail address: vejrik.lukas@seznam.cz (L. Vejř́ík).
} 
realized their non-substitutability in the ecosystem (Veit et al., 1997; Myers et al., 2007; Stone, 2007; Ferretti et al., 2010). The main freshwater apex predator in Europe is the European catfish (Silurus glanis) and its native area is Central and Eastern Europe (Copp et al., 2009). Catfish is the biggest freshwater fish in Europe and the third biggest freshwater fish in the world (Stone, 2007; Copp et al., 2009). This may be the reason why there are a lot of myths connected with the catfish. Moreover, it is difficult to study, so practically no information was known about it for decades (Boulêtreau and Santoul, 2016). Knowledge about the ecology of catfish has been progressively revealed in the last years (Syväranta et al., 2010; Guillerault et al., 2015; Vejř́ík et al., 2017b). The insufficient number of studies focused on catfish is mainly caused by the low efficiency of standard sampling methods (Alp et al., 2003). Methods used for capturing catfish are described in Supplementary materials (S1). It is difficult to capture catfish despite the fact that the number of catfish is generally increasing in comparison to other apex predators (Carol et al., 2007; Copp et al., 2009; Cucherousset et al., 2012; Cunico and Vitule, 2014). However, the populations of catfish in its native area cannot practically reach carrying capacity due to rather intensive fishing (Copp et al., 2009). For instance, 6543 tons of catfish were caught in the previous decade, whereas 8096 tons were caught in the last decade in Russian Federation (Fig. 1). In native localities, catfish is a subject of both angling and commercial fishing due to its high-quality meat (Linhart et al., 2002).

Catfish has also been introduced to new localities such as Western and Southern Europe where it is regarded as an invasive species (Carol et al., 2007; Cucherousset et al., 2012). It is a paradox, that no commercial fishing, angling or harvesting is provided in non-native localities where catfish is unwanted species. No catches of catfish are registered in statistics of Food and Agriculture Organization (FAO) from Belgium, Netherlands, Spain or Italy. Limited harvest from Western Europe is probably known only from France, where on average 35 tons of catfish is caught from the open freshwaters. However, this biomass recorded from France is markedly lower than biomass of catfish caught in native countries (FAO, 2018, Fig. 1). Invasions are in general serious threats to freshwater ecosystems (Dudgeon et al., 2006). Recent work in Germany and the USA has shown that body size is a key determinant of angler motivation across a range of species (Arlinghaus et al., 2014). The large body size of catfish is the main reason for illegal introduction outside its native range (Hutt et al., 2013; Cucherousset et al., 2018). Catfish as an apex predator may dramatically affect localities such as
Iberia and other countries in Southern Europe where high endemism of small-bodied fish species combines with an absence of native piscivorous fishes (Copp et al., 2009). These species-unsaturated localities are more susceptible to invasion by non-native species because there is a vacant ecological niche and interspecific competition is less intense (Kennedy et al., 2002). According to the Fish Invasiveness Scoring Kit (FISK), catfish poses a high risk in these areas (Almeida et al., 2013), whereas this fish is classified in medium risk category according to European Union (Copp et al., 2014). Considering the wide diet plasticity of catfish (Vejř́k et al., 2017b), it affects not only fishes, but also other vertebrates such as waterfowl (Carol et al., 2009).

Catfish is a successful apex predator that fundamentally influences the ecosystem (Copp et al., 2009; Vejř́k et al., 2017b). Thus, the impact may be profitable but also extremely unfavourable depending on the locality. Catfish has several unique characteristics that pose it to a role of an ideal species for biomanipulation, such as low requirements for water quality, longevity, tolerance to manipulation (Copp et al., 2009), ability to form abundant population (Boulêtreau et al., 2011), wide diet plasticity and lower gape limitations in comparison with other predators (Vejř́l et al., 2017b; Boulêtreau et al., 2018). Biomanipulation may be applied to obtain or maintain high water quality in reservoirs for drinking water (Vašek et al., 2013) or in recreational water bodies such as post-mining lakes (Vejř́k et al., 2017b). High potential is assumed in a mild climate due to good prosperity of catfish in warmer water (Britton et al., 2007).

In terms of the impact of angling on catfish, only two studies, to our knowledge, have been published so far (Britton et al., 2007; Boulêtreau et al., 2016), however these studies did not evaluate the required impact of angling on the catfish population (Cadrin and Pastoors, 2008). Due to, increasing importance of the species, present study reveals needed information about control of catfish population in localities with its unwanted presence, but also catch and mass quotas of catfish for localities with its wanted presence that will ensure long-term sustainability of the populations. Further, we evaluated the financial budget of a catfish fishery that is commonly ignored. In addition, we used hook-lines, an efficient method for capturing catfish (Vejř́k et al., 2017b), which can be used for both scientific and manipulation (regulatory) purposes. Catfish individuals in the study sites were tagged, their abundances and biomasses were known and thus our study has a unique experimental design conducted under natural conditions. The main findings are discussed in two sections focused on i) sustainability

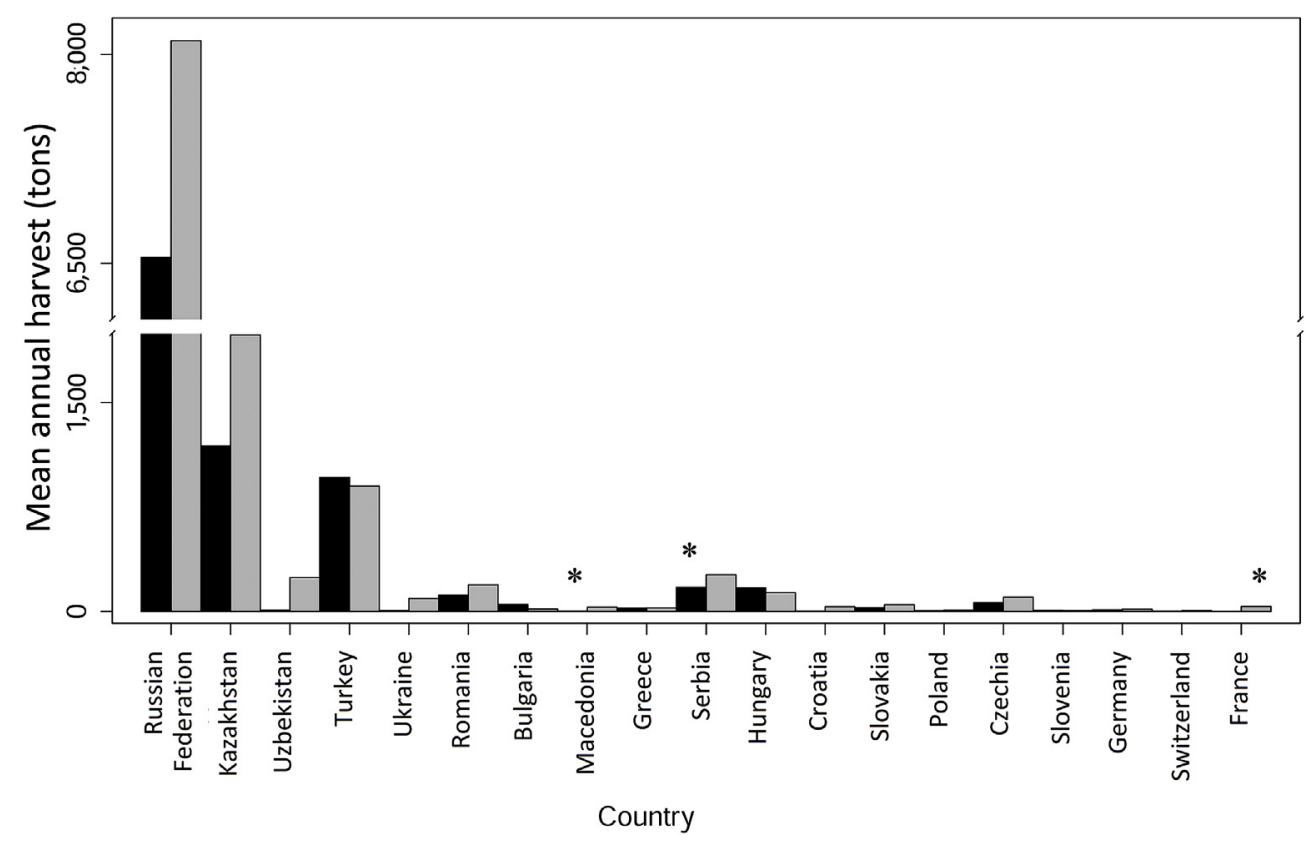

Fig. 1. Mean annual harvest of catfish in tons from open freshwaters in countries where harvesting is carried out according to FAO statistics (FAO, 2018). Countries are sorted geographically from east to west. Columns show mean annual harvest in tons in 1997-2006 (black columns) and 2007-2016 (grey columns). *Macedonia (average only for 2005-2016), *Serbia (only for 2006); *France (average only for 2012-2016). 


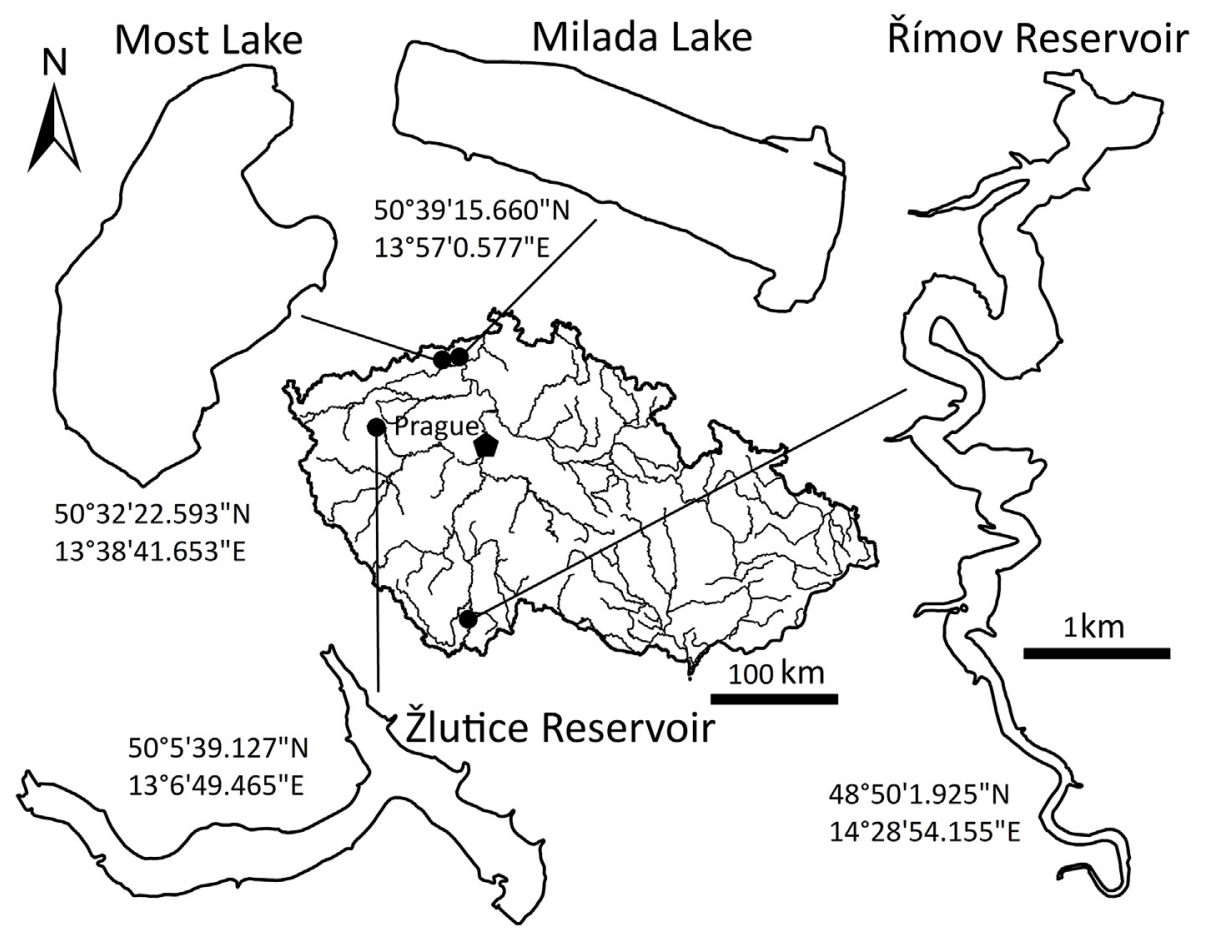

Fig. 2. Study sites with GPS locations marked in the map of the Czech Republic (capital: Prague).

of catfish population when the desired management outcome is either water quality or angling opportunities, and ii) usage of hook-lines as a tool to reduce an invasive species.

\section{Material and methods}

\subsection{Study sites}

The study was conducted in two water bodies created after aquatic restorations of lignite mining pits, Milada and Most Lakes, Czech Republic (Fig. 2). The oligo-to mesotrophic Milada (250 ha, $36 \times 10^{6} \mathrm{~m}^{3}$, max. depth $25 \mathrm{~m}$ ) was flooded with water between 2001 and 2010. European catfish was introduced in 2007 (316 individuals, mean mass $1.2 \mathrm{~kg}$ ) for biomanipulation purposes. The oligotrophic Most (311 ha, $70 \times 10^{6} \mathrm{~m}^{3}$, max. depth $75 \mathrm{~m}$ ) was flooded between 2008 and 2014. European catfish (694 individuals, mean mass $3.7 \mathrm{~kg}$ ) was introduced in 2011, 2012 and 2013. In Most, all catfish individuals were individually tagged with a passive integrated transponder tag (PIT-tag, Oregon RFID, fullduplex, length $12 \mathrm{~mm}$, diameter $2.15 \mathrm{~mm}$, weight $0.11 \mathrm{~g}, 11,784 / 11,785$ compatible). In Milada, catfish individuals were tagged when they were captured by hook-lines. Both lakes present a new type of water body that appears throughout Europe nowadays (Sienkiewicz and Gasiorowski, 2017) and both were naturally colonized by perch (Perca fluviatilis), rudd (Scardinius erythrophthalmus), roach (Rutilus rutilus) and ruffe (Gymnocephalus cernua; for details see Vejř́íková et al., 2016). Maintaining good water quality is an important feature of both lakes and fish predators play the main role in biomanipulation there (Vejř́k et al., 2017b). Angling is currently forbidden, however it is expected to be allowed in the future. Two dam reservoirs for drinking water were used as reference sites: Ǩímov Reservoir ( $210 \mathrm{ha}, 34 \times 10^{6} \mathrm{~m}^{3}$, max depth $45 \mathrm{~m}$ ) and Žlutice Reservoir (161 ha, $16 \times 10^{6} \mathrm{~m}^{3}$, max. depth $23 \mathrm{~m}$ ) (Fig. 2). Both reservoirs are eutrophic, and catfish are stocked regularly (50 individuals, i.e. ca. $110 \mathrm{~kg}$ per year) for biomanipulation purposes (for more details see Vašek et al., 2013).

\subsection{Fish sampling}

Animal treatment (including fish sampling and stomach content analysis) was performed in accordance with guidelines from the Experimental Animal Welfare Commission under the Ministry of Agriculture of the Czech Republic (Ref. No. CZ 01679) and with permission of Palivový kombinát Ústí, state enterprise, the owner of Milada and Most Lakes, and the Vltava River Authority, administrator of Římov and Žlutice Reservoirs. The work was approved by the Ethics Committee of the Czech Academy of Sciences. The field study did not involve endangered or protected species.

European catfish from both lakes and both reservoirs were caught by hook-lines. The method is illustrated in the Graphical abstract and a detailed description may be found in Supplementary materials (S2) and Vejř́k et al. (2017a). Altogether 30 individual bait fish on 3 hook-lines were used each day of sampling. Most of the catfish were caught during the night (81-98\%; depending on the water body). All individuals were measured (total length, $\mathrm{L}_{\mathrm{T}}$ ) and the codes of their pit-tags were recorded. We spent 32, 28, 12 and 8 days in Most, Milada, Římov and Žlutice, respectively.

To obtain reliable estimates of the fish biomass of the entire fish community, detailed sampling was conducted in all water bodies between 2012 and 2016; between July and September. Each water body was sampled during the course of 4-5 days in one year by multimesh gillnets according to EU standard (CEN, 2015; for details see Blabolil et al. (2017)).

\subsection{Simulation of anglers activities}

Hook-lines (Vejř́ík et al., 2017a) authentically simulate angling with a supporting buoy that is commonly used for catfish angling. The two baits simulate the two tips that are normally used by one angler, so that we simulated 15 anglers each day. See supplementary materials (S2) for a detailed description of the simulation of angling in accordance with current fishing regulations of the Czech Fishing Union (CFU, 2017).

The simulations were conducted in June-July 30-4, August 25-28, September 15-19 and November 17-21 in Milada Lake, and in June 23-27, August 18-22, September 1-5 and November 4-8 in Most Lake. 
Table 1

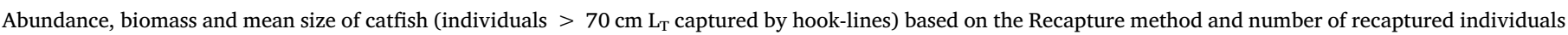
in Milada and Most Lakes, and Římov and Žlutice Reservoirs.

\begin{tabular}{|c|c|c|c|c|c|c|c|}
\hline Locality & Estimated size of the population & Ind. ha ${ }^{-1}$ & Biomass ha ${ }^{-1}$ & Mean mass (kg) & Mean length $(\mathrm{cm})$ & No. of caught individuals & No. of recaptures \\
\hline Milada & 186 & 0.74 & 6.1 & 8.2 & 103 & 93 & 37 \\
\hline Most & 576 & 1.85 & 7.6 & 4.1 & 85 & 232 & 74 \\
\hline Římov & 211 & 1.00 & 11.8 & 11.7 & 116 & 47 & 3 \\
\hline Žlutice & 167 & 1.04 & 8.5 & 8.2 & 102 & 57 & 6 \\
\hline
\end{tabular}

The sampling campaigns covered basically the entire angling season (between June 16 and December 31, i.e. 199 days per year). Catches from May (May 3-7 in Milada, May 9-13 in Most) were not used for calculations due to national prohibition of angling for predatory fish. Catfish larger than $70 \mathrm{~cm}$ were used to calculate the angling pressure (see Supplementary materials S3). It is impossible to catch all individuals of catfish from the locality on bait, thus it is practically impossible to reduce fish population to $0 \%$ of the previous size (Britton et al., 2007). That is why our results show reduction to $10 \%$ as a terminal value. Sampling campaigns in the reference reservoirs were conducted in 2017 in April 17-21, May 15-19 and July 17-21 in Římov Reservoir, and in May 22-26 and July 24-28 in Žlutice Reservoir.

\subsection{Temperature}

Water temperature was measured between 12:00 and 14:00 during the sampling campaign at each site. Measurements were made at $1 \mathrm{~m}$ depth intervals using a calibrated YSI 556 MPS probe (YSI Incorporated-Yellow Springs, Ohio, USA). The temperature of the epilimnion was used for the purpose of this study since catfish is a warm water species (Copp et al., 2009).

\subsection{Statistical analyses}

Mark and Recapture calculations (Schnabel, 1938) were used to estimate the number of individuals in a population, i.e. population size in our study and reference sites:

$N=\frac{\sum_{i=1}^{m} M i C i}{\sum_{i=1}^{m} R i}$

where $N$ stands for population size, $M i$ for total number of previously marked animals at time $i, C i$ for number of individuals caught at time $i$, and $R i$ for number of marked animals caught at time $i$.

Survival rate of the catfish population per one visit (S) is calculated as

$\mathrm{S}=\frac{\mathrm{N}-\mathrm{U}_{1}}{\mathrm{~N}}$

where $U_{1}$ is the catch per one visit calculated as the total number of catches within the month divided by 60 , since catching effort applied in each month was equivalent to 30 full-day visits of one anglers with two rods.

Mortality rate caused by anglers per one visit ( $z$ ) was calculated as: $\mathrm{z}=-\operatorname{In} \mathrm{S}$

Efficiency of the catching differed during the year, thus $z$ was calculated for each month separately (June-July, August, September and November). Values for the missing months were calculated as means of the previous and the following month.

The number of individuals in the population, with regard to mortality rate (caused by anglers or hook-lines), was calculated as:

$N_{t}=N_{0} * e^{-z * E}$

where $N_{O}$ stands for the number of individuals in the previous day, and $E$ for expected catching effort in a given day (i.e. number of visit of anglers).
The decrease of the catfish population was modelled day by day in the angling season for all sites. Natural mortality was considered as negligible in comparison to mortality caused by anglers.

The mean cost of $1 \mathrm{~kg}$ of catfish sold as a live fish (7.5€) was set in accordance with companies selling fish meat registered in The Czech Fish Farmers Association (www.cz-ryby.cz). A fishing licence in accordance with the Czech Fishing Union costs $44.5 €$ in 2017 (valid all year) and allowed fishing in one region (in our case, 111 fishery localities of the total area 4621 ha) of the Czech Republic (CFU, 2017).

The effect of temperature and season on catfish catch rate was tested by general linear model (GLM), where lake identity was set as random factor.

Five variables - prey fish biomass (fish up to $2.5 \mathrm{~kg}$ mass), trophic status (total phosphorus), number of catfish in the water body, biomass of catfish in the water body and mean size of catfish - were used to identify the best model that explained catfish catch per 10 baits during a day. Stepwise linear regression without interaction terms was applied to choose the model with maximum likelihood, as determined by the lowest Akaike Information Criterion (AIC) value (Venables and Ripley, 2002). The AIC deals with the trade-off between the goodness of fit of the model and the simplicity of the model (number of variables), or the risk of overfitting and the risk of underfitting (Sakamoto et al., 1986).

All statistical analyses were conducted using $\mathrm{R}$ software version 3.4.2 (R Core Team, 2017).

\section{Results}

Number of caught catfish, their lengths, masses and estimated size of their populations (individuals $>70 \mathrm{~cm} \mathrm{~L} \mathrm{~L}_{\mathrm{T}}$ ) in individual water bodies based on the Recapture method are summarized in Table 1.

\subsection{Catch efficiency dependent on season}

May was the second most efficient month in both Milada and Most. The first half of the sampling campaign was more efficient than the second in both lakes. Water temperature ranged from 12.1 to $16.3^{\circ} \mathrm{C}$ during sampling in May (Fig. 3). Catfish catch rate was significantly dependent on season (GLM, $\mathrm{F}_{1,2}=10.0, p<0.01$ ) contrary to temperature (GLM, $\mathrm{F}_{1,1}=0.8, p>0.05$ ). The most efficient time was June-July (water temperature $19.1-20.2^{\circ} \mathrm{C}$ ). The mean efficiency was 2.8 and 5.4 individuals per 10 baits in one day for Milada and Most, respectively. Efficiency of catching had a decreasing tendency in the following months, even in August when the water temperature was the highest $\left(22.1-23.5^{\circ} \mathrm{C}\right)$. In terms of the reference sites, the catch efficiency was 1.8 individuals per 10 baits in one day for Římov in April. In May it was 0.75 and 2.4 individuals per 10 baits in one day for Římov and Žlutice, respectively. In July it was 1.3 and 2.8 individuals per 10 baits in one day for Římov and Žlutice, respectively.

\subsection{Parameters influencing the catfish catch}

The most parsimonious model identified by stepwise linear regression for catfish catch per 10 baits during a day with the lowest AIC consisted of two parameters:

No. of Catfish 10 baits $^{-1}$ Day ${ }^{-1}=5.098^{*}-0.494$ Mean length of 
(a)

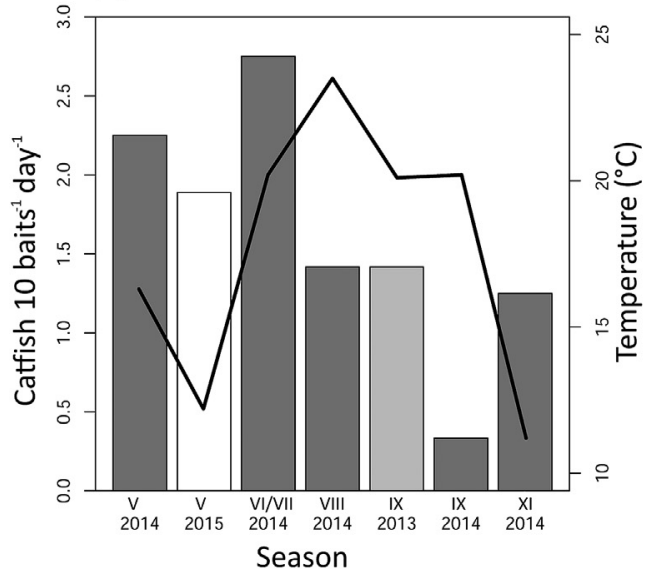

(b)

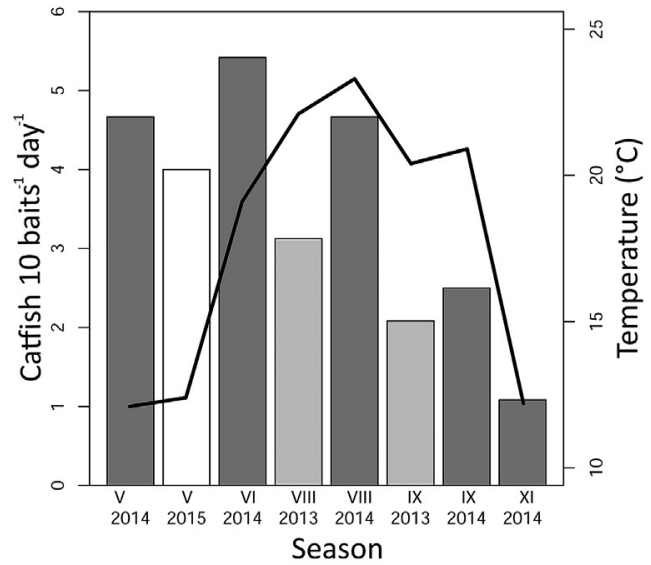

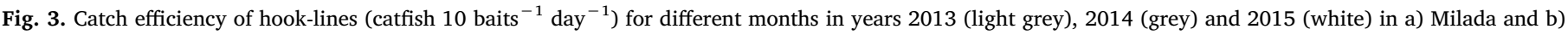
Most. Mean temperature of the epilimnion is represented by a curve.

catfish* +0.177 Biomass of catfish (AIC $=-15.24$, adj. $\mathrm{R}^{2}=0.988$, $p=0.063$, length in $\mathrm{mm}$, biomass in $\mathrm{kg} \mathrm{ha}^{-1}$ ).

Asterisk indicates the significance levels at which the estimated parameters in the model formula differ from zero: * for $p<0.05$. The model predicted a negative influence of mean size of catfish, and a positive effect of catfish biomass. The variables as prey fish biomass, trophy and number of catfish in the locality were not chosen by the model. Model predictions closely matched observations with all observations falling in the $95 \%$ prediction confidence interval (Fig. 4).

\subsection{Simulation of reduction of catfish population}

In total, 3582 bait-days would be needed to reduce the catfish population to $10 \%$ of the original size in Milada, i.e. 14.3 bait-days per 1 ha (average for the entire angling season between June 16 and December 31). It corresponds to the visits of nine anglers each day during the entire season per lake (Fig. 5a). If 20 anglers visited Milada

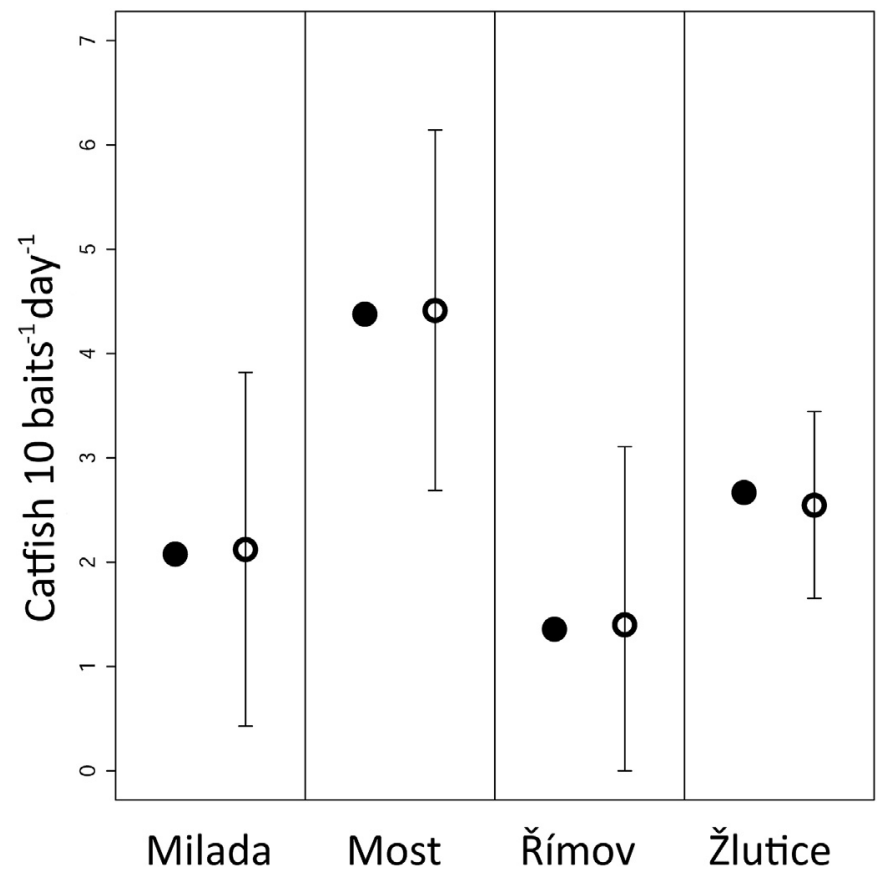

Fig. 4. Comparison of observed catfish catch per 10 baits during a day (black dots) and model predictions (empty dots) with 95\% confidence interval (error bars) in all study and reference sites. each day, the catfish population would be reduced to $10 \%$ already on August 1, i.e. after 46 days of the angling season.

In total, 4776 bait-days would be needed to reduce the catfish population to $10 \%$ in Most, i.e. 15.4 bait-days per 1 ha (average for the entire angling season between June 16 and December 31). It corresponds to the visits of 12 anglers each day during the entire season per lake (Fig. 5b). If 20 anglers visited Most each day, the catfish population would be reduced to $10 \%$ already on August 21, i.e. after 66 days of the angling season.

In terms of reference sites, 3800 and 1840 bait-days are needed to reduce the catfish population to $10 \%$ in Ǩímov and Žlutice, respectively. It corresponds to 18 and 11 bait-days per 1 ha in Rímov and Žlutice, respectively. If 20 anglers visited Římov and Žlutice each day, the catfish population would be reduced to $10 \%$ after 95 and 46 days, respectively.

\section{Discussion}

A method of hook-lines was described in this study as an efficient method for capturing catfish. We evaluated its efficiency as a mechanism for catfish regulation, compared this method with regular angling and evaluated the financial impact of the issue. Further, we focused on the benefits and threats connected with the presence of catfish depending on the locality.

Based on the Recapture method, the catfish population in Most was estimated at 576 individuals, this is $\mathbf{1 7 \%}$ less than the total number of stocked individuals (694). This somehow corresponds to the natural mortality of farmed and subsequently stocked fish which is roughly estimated to be around 10\% (Copp et al., 2009). Natural recruitment of catfish in Most was not considered due to its short presence in the lake (3 years) when early recruits would not have reached sufficient length (Vejř́l et al., 2017b). Thus, error in estimate should be under 10\% and so the results based on Recapture method can be considered as valid (Robson and Hegier, 1964). Estimations of the catfish population in Milada, Žlutice and Ǩímov were 186, 167 and 211, respectively. Seber (1982) recommended two estimators of reliability of the estimated population size. The estimated value is unbiased if $(\mathrm{M}+\mathrm{C}) / \mathrm{N} \geq 1$ and nearly unbiased if there are at least seven recaptures of marked animals $(\mathrm{R}>7)$. In our case, $(\mathrm{M}+\mathrm{C}) / \mathrm{N}$ for Žlutice and Ǩímov (reference reservoirs) were 0.4 and 0.2 indicating a certain distortion of the estimated population size. The values were 0.7 and 0.5 for the main study sites Milada and Most Lakes, respectively, indicating a low distortion. The sufficient number of recaptures $(\mathrm{R}>7)$ was not reached in Římov and Žlutice with only 3 and 6 recaptured individuals, respectively. Whereas 37 and 74 individuals were recaptured in Milada and Most, 
(a)

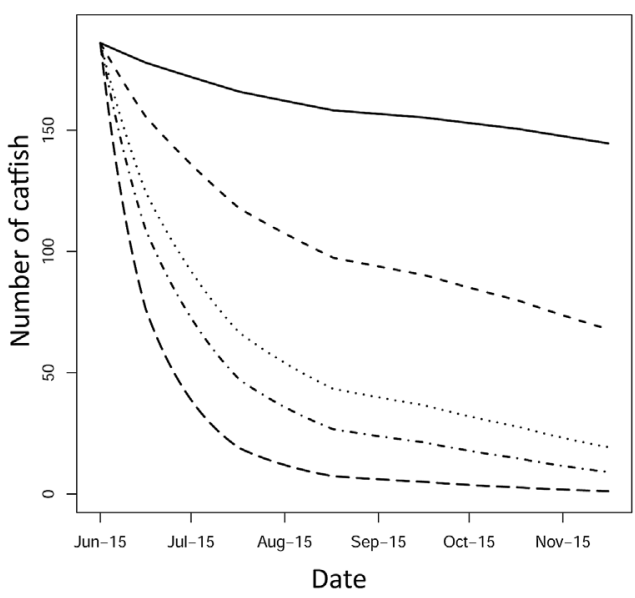

(b)

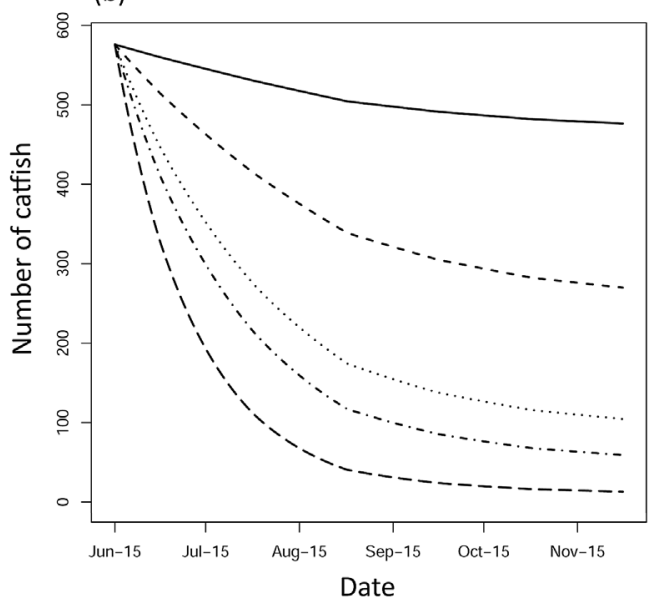

Fig. 5. Modelled impact of anglers on the catfish populations in a) Milada and b) Most Lakes within one season depending on daily visit rate. The model demonstrates visits of one angler (solid line), three (dashed line), five (dotted line), eight (dot-dashed line), and 12 anglers for Milada and 20 anglers for Most (bold dashed lines). The last bold dashed lines correspond to number of anglers causing decrease of catfish population to $10 \%$ of the original size within one angling season. respectively. Thus, the estimated population sizes should be very close to real values in Milada and Most Lakes, whereas we can consider a certain distortion in comparison to real values in Římov and Žlutice.

The first scenario of the catfish population in the ecosystem is its beneficial presence. Wysujack and Mehner (2005) claimed that catfish is not efficient as a biomanipulative species. However, their study is based on small catfish (mostly $<80 \mathrm{~cm} \mathrm{~L}_{\mathrm{T}}$ ), which is hardly sufficient considering its growth potential (up to $250 \mathrm{~cm} \mathrm{~L}$; Boulêtreau and Santoul, 2016). This is probably the reason why Vejř́l et al. (2017b) or Boulêtreau et al. (2018) presented entirely opposite results, i.e. clear impact of catfish on the entire fish community, including frequent consumption of large prey (up to $c a .70 \mathrm{~cm} \mathrm{~L}_{\mathrm{T}}$ and $c a .3 \mathrm{~kg}$ ). The diet spectrum of catfish is wide, thus the entire fish community is affected by predation pressure that is spread evenly across species, which means moderate pressure on a particular species (Syväranta et al., 2010). Therefore, the high effect of biomanipulation provided by catfish may be achieved by maintaining of a numerous population (Vejř́ík et al., 2017b). In contrast to other fish predators, catfish is able to survive at high density in the ecosystem thanks to its low cannibalism (Vejř́k et al., 2017b) and long lifespan (Copp et al., 2009). Biomanipulation efficiency may be noticeably increased by a synergic predation effect, when pike and perch are the additional predators present in the system (Wasserman et al., 2016).

Access to anglers according to the rules of the Czech Fishing Union would cause a decrease in the catfish population to over $90 \%$ during the first season in both study sites. Daily visits of 9 and 12 anglers from June 16 to December 31 would be enough in Milada and Most, respectively. The consequences would be i) severe decrease of biomanipulative effect (Vejř́ík et al., 2017b), ii) loss of ecologically stable population, and iii) substantial financial losses to the fishery. Comparing the income from licences and the costs of fish captured, the seasonal financial loss in Milada would be $10,295 €(41.2 €$ per ha) corresponding to 231 of sold annual fishing licences. The seasonal financial loss in Most would be 15,941 € (51.4€ per ha) corresponding to 358 of sold annual fishing licences. At the beginning of the angling season, each angler would catch on average 0.5 and 1.1 catfish per visit to Milada and Most, respectively. Considering the mean mass of catfish ( $8.2 \mathrm{~kg}$ and $4.1 \mathrm{~kg}$ in Milada and Most, respectively), it would correspond to an angler's theoretical income of $30.75 €$ and $33.83 €$ per visit, which is $69 \%$ and $76 \%$ of the cost of the annual fishing licence. The angling success would naturally quickly decrease depending on the visit rate and numbers of remaining catfish. The cost of one multi-hooks system used for hook-lines (excluding bait fish) ranges from $5.5 €$ (medium quality) to $10 €$ (high quality) and a standard hook-line contains 10 multi-hooks systems. Its durability is between 5 and 11 of caught fish but the ideal time for replacement is after six caught fish. Thus, angler's profits from fish caught on one multi-hooks system were
307.5-676.5 $€$ and 153.8-338.3 $€$ for Milada and Most, respectively. These basic economic calculations, considering cost of captured catfish versus cost of fishing licences, showed that this system would be unsustainable. As mentioned by Boulêtreau et al. (2016), different fish species vary in their reaction to attempts to recapture. Either a hook avoidance induced by angling pressure (Young and Hayes, 2004; Fernö and Huse, 1983) or an opposite reaction (Morita and Tsuboi, 2004) or an unaffected catchability (Beukema, 1970) was observed. The catchability of catfish seems to be unaffected (Boulêtreau et al., 2016), or to the contrary, it slightly increases with recapturing (Britton et al., 2007; Boulêtreau et al., 2016). The latter theory is also supported by the substantial frequency of recaptures in Milada and Most (34 and 32\%, respectively). Regarding the fact that catfish (Britton et al., 2007) and pike (Beukema, 1970) do not react to angling pressure by hook avoidance and do not have timidity syndrome (Arlinghaus et al., 2016). "Catch and Release" angling (Arlinghaus et al., 2007) practised by a part of the anglers would not ensure a sufficient number of predators. Most of the anglers in Central and Eastern Europe still prefer taking the fish (Spurný et al., 2017) because the species is considered to be a culinary delicacy (Copp et al., 2009). These reasons demonstrate that sustainable populations of predators including catfish in localities designed for recreational fishing can be maintained only with strict regulation of the angling and with regular stocking of new individuals (Johnston et al., 2010). Thus, the regular angling for predators should not be permitted in the post-mining lakes Milada and Most and in similar lakes that are newly appearing around Europe, nor in drinking water reservoirs such as Římov and Žlutice (Vašek et al., 2013).

Maximum efficiency, presenting levels of optimal angling pressure (in terms of population sustainability), economic return and ecological self-sustainability, would be ensured under the following conditions. If we want to provide a sustainable angling, capturing of individuals between 75 and $120 \mathrm{~cm}$ is a good option. Meat quality of such middlesized individuals seems to be optimal because meat from larger individuals is high in fat with low taste (Linhart et al., 2002). In contrast, these large individuals have the most positive impact on the ecosystem thanks to no gape limit and it is advisable to keep them in the water bodies (Vejř́k et al., 2017b). We observed that natural recruitment of catfish $\left(20-25 \mathrm{~cm} \mathrm{~L}_{\mathrm{T}}\right.$ ) is relatively high in both post-mining lakes (L. Vejř́k, P. Blabolil, pers. observation by electrofishing). Age at maturity in catfish is generally reported as being 3-4 years old, with mean length at maturity ranging from 39 to $71 \mathrm{~cm} \mathrm{~L}_{\mathrm{T}}$ (Copp et al., 2009 and related studies). Mean growth rate of catfish occurring $50^{\circ}$ north (such in Czechia or Slovakia) is $8 \mathrm{~cm}$ per year (Baruš and Oliva, 1995). In contrast, growth rate can be even between 10 and $15 \mathrm{~cm}\left(\max 20 \mathrm{~cm} \mathrm{~L}_{\mathrm{T}}\right.$ ) in milder climate, such as in Romania and France (ca. $45^{\circ}$ north latitude; Copp et al., 2009). Therefore, it takes about 8 and 4 years to exceed the length for angling of individuals occurring $50^{\circ}$ and $45^{\circ}$ north, 
respectively. Study sites contain on average 120 individual catfish per 100 ha. If we want to preserve $10 \%$ of individuals up to $120 \mathrm{~cm}$, about 13.5 and 27 individual catfish $\left(\mathrm{L}_{\mathrm{T}}\right.$ between 75 and $120 \mathrm{~cm}$ ) can be captured per 100 ha of water bodies in $50^{\circ}$ and $45^{\circ}$ north, respectively. It means about 100 and 200 bait-days per 100 ha in one year.

If the mentioned rules are respected, biomanipulative effect of catfish should be sufficient (Vašek et al., 2013) with regards to maximum economic prosperity of angling. However, the recommendations should be approached with caution, because individuality of each locality should be considered. Ideal scenario is to provide a before after control impact of catfish population on the locality within several years. It could be a crucial topic for further similar studies.

The second scenario of the catfish population in the ecosystem is its unwanted presence. Catfish is an invasive species in many areas located in Western and Southern Europe where it can affect native fish communities including endemic species (Copp et al., 2009). Fast spreading is mediated mainly by anglers, even to localities with temperaturesuboptimal conditions such as the United Kingdom (Britton et al., 2007; Copp et al., 2007), regardless of the fact that the spreading is illegal (Britton et al., 2010a, 2011). We can assume that the impact of catfish in localities such as the UK will be higher in the future due to increasing temperature caused by climate changes (Vejř́k et al., 2017a). According to available information, catfish probably presents the greatest threat in the Iberian Peninsula (Copp et al., 2009; Almeida et al., 2013). Catfish is an unwanted species also in Italy where it reaches maximum large sizes (Boulêtreau and Santoul, 2016). Therefore, release of catfish to aquatic ecosystems is forbidden by law (legge regionale n. 19 del 28 aprile 1998). Unfortunately, valuable scientific results focusing on catfish impact on water systems in Italy are not available. In contrast, localities in France seem not to be negatively influenced so far, however long-term observations are necessary (Guillerault et al., 2015). When catfish is unwanted, the ability to extirpate a local population is practically impossible because catfish prefers large aquatic ecosystems with high connectivity (Britton et al., 2010a b). Consequently, the catfish is still expanding its range and population sizes are increasing in Belgium, France, the United Kingdom and Spain despite angling regulations aimed at the reduction of this species (Cucherousset et al., 2018). Anglers catching catfish in Western and Southern Europe commonly prefer the "Catch and Release" method (Arlinghaus et al., 2007) in good faith to maximize welfare of fish (Arlinghauss et al., 2007b). As such, this capturing method cannot be used for reduction of catfish populations.

However, a catfish population and its potential negative impact can be readily reduced by targeted capturing. Thus, we would recommend hook-lines as an efficient method in hands of managing stakeholders for catfish regulation in localities with unwanted presence of this large invasive species. Because the hook-lines efficiently reduce the number of predators in marine ecosystems (Cardinale et al., 2015), it clearly must be even more efficient in much smaller freshwater ecosystems. Moreover, this fact was proved by our results. The pressure provided by anglers or regulation by hook-lines will not completely remove catfish from a locality. Nevertheless, the methods have substantial impacts on catfish population from reduced abundance and biomass (Hutchings and Myers, 1994; Toresen and Østvedt, 2001), to truncated age and size structure (Jørgensen, 1990), and altered population genetic subdivision up to erosion of genetic diversity (Allendorf et al., 2008). Therefore, the population is reduced down to a harmless level by these methods and the localities where catfish is invasive and unwanted should recover.

Theoretically, 11-18 bait-days per 1 ha per season are needed to reduce the local population of adult catfish to $10 \%$ of the original size (population size between 0.74 and 1.85 ind. ha $^{-1}$ ). Neither prey fish biomass, trophic status, nor number of catfish in the locality had a significant impact on the catch efficiency. In contrast, the size of the catfish had a significant impact on the catch efficiency, as small individuals are more readily caught than large ones. Further, efficiency increases with catfish biomass in a locality. The model used in the study proved that catfish biomass is a better index of potential predation pressure of catfish than number of catfish in a locality. All catfish populations in our study and reference sites are large in comparison to other aquatic ecosystems in the Czech Republic (Vašek et al., 2013; Vejř́ík et al., 2017a). The reasons are i) absence of anglers' activities and ii) man-mediated vast stocking programme at the study sites. Thus, we assume the presence of larger populations only in localities with more favourable conditions and with a warmer climate (Copp et al., 2009). Unfortunately, estimates of the size of catfish populations in absolute majority of European localities are still not available. However, catching effort intensified to 30-40 bait-days per 1 ha per a year should be sufficient to reduce a catfish population to $10 \%$ of the original size in any European locality. Determination of the population size is necessary to calculate an accurate number of bait-days for a given locality. Spring and early summer seems to be the best time for the highest catch efficiency, i.e. time close to reproduction (Copp et al., 2009). The efficiency decreases towards autumn and winter. Higher impact of season than temperature was statistically proved and was also assumed by Britton et al. (2007).

If we want to apply hook-lines in the countries of the European Union, it is necessary to overcome the deep-rooted tradition that a lot of freshwater ecosystems serve only as an angling area and no other regulations are applied (Lewin et al., 2006). Further, the policy of each country will specify, whether ecologically sustainable management will be preferred opposed to the maintenance of hobby and relaxation facilities for many inhabitants, because big game fishing provides satisfaction for anglers (Arlinghaus et al., 2002; Matsumura et al., 2011). Moreover, angling brings economic benefits thanks to the sale of licences and fishing equipment (Jørgensen et al., 2007). It has to be mentioned, that catfish can be even beneficial in some cases in nonnative localities, because it can reduce abundances of many other invasive species (Carol et al., 2009). Thus, an individual approach is necessary in each locality. Providing a study focused on catfish diet in the locality (Vejř́k et al., 2017a) would be an ideal step before making a decision about catfish reduction or maintenance.

\section{Conclusions}

To maintain an efficient biomanipulative effect of catfish in the localities with wanted presence, angling pressure should be limited to only 1 and 2 bait-days per 1 ha in one year in $50^{\circ}$ and $45^{\circ}$ north latitude, respectively. Only individuals with sizes between 75 and $120 \mathrm{~cm} \mathrm{~L}$ should be allowed to harvest.

In contrast, if population control of European catfish is needed, the most efficient time of the year to apply hook-lines seems to be spring to early summer. Subsequently, the feeding activity of catfish decreases. The sufficient catching effort seems to be $30-40$ bait-days per 1 ha per season to efficiently reduce the catfish population to $10 \%$ of the original size in any European locality.

\section{Authors contributions}

L.V. conceived the project and designed the methodology, P.B. and J.K. conducted the statistical analysis, L.V., P.B. and Z.S. did the figures, L.V., L.K., Z.S., M.Š., T.J., P.B., T.K., D.B., I.V. and J.P. collected field data, J.P. and J.K. provided financial support, L.V., I.V., M.Č. and P.B. wrote the manuscript. All authors contributed critically to the drafts and gave final approval for publication.

\section{Competing interests}

The authors declare no competing interests.

\section{Data availability}

Data will be available on a reasonable request. 


\section{Acknowledgements}

This study was supported by SoWa Research Infrastructure funded by MEYS CZ - programme "Project of Large Infrastructure for Research, Development, and Innovations" (No. LM2015075), by European Regional Development Fund - project "Research of key soil-water ecosystem interactions at the SoWa Research Infrastructure" (No. CZ.02.1.01/0.0/0.0/16_013/0001782), by ERDF/ESF - project "Biomanipulation as a tool for improving water quality of dam reservoirs" (No. CZ.02.1.01/0.0/0.0/16_025/0007417), by the European Union's Horizon 2020 research and innovation programme - project "Co-creating a decision support framework to ensure sustainable fish production in Europe under climate change" (No. 677039), and finally by the Applied Research Program of the Ministry of Agriculture project "Methodology of predatory fish quantification in drinking-water reservoirs to optimize the management of aquatic ecosystems" (No. QK1920011). We thank Ingrid Steenbergen for editing the English and the reviewers for their valuable comments.

\section{Appendix A. Supplementary data}

Supplementary data to this article can be found online at https:// doi.org/10.1016/j.jenvman.2019.04.005.

\section{References}

Allan, J.D., Abell, R., Hogan, Z., Revenga, C., Taylor, B.V., Welcomme, L.R., Winemiller, K.O., 2005. Overfishing of inland waters. Bioscience 55, 1041-1051.

Allendorf, F.W., England, P.R., Luikart, G., Ritchie, P.A., Ryman, N., 2008. Genetic effects of harvest on wild animal populations. Trends Ecol. Evol. 23, 327-337.

Almeida, D., Ribeiro, F., Leunda, P.M., Vilizzi, L., Copp, G.,H., 2013. Effectiveness of FISK, an invasiveness screening tool for non-native freshwater fishes, to perform risk identification assessments in the Iberian Peninsula. Risk Anal. 33, 8.

Alp, A., Kara, C., Buyukcapar, H.M., 2003. Reproductive biology in a native European catfish, Silurus glanis L., 1758, population in menzelet reservoir. Turk. J. Vet. Anim. Sci. 28, 613-622.

Arlinghaus, R., Mehner, T., Cowx, I.G., 2002. Reconciling traditional inland fisheries management and sustainability in industrialized countries, with emphasis on Europe. Fish Fish. 3, 261-316.

Arlinghaus, R., Cooke, S.J., Lyman, J., Policansky, D., Schwab, A., Suski, C., et al., 2007. Understanding the complexity of catch-and-release in recreational fishing: an integrative synthesis of global knowledge from historical, ethical, social, and biological perspectives. Rev. Fish. Sci. 15, 75-167.

Arlinghauss, R., Cooke, S.J., Schwab, A., Cowx, I.G., 2007. Fish welfare: a challenge to the feelings-based approach, with implications for recreational fishing. Fish Fish. 8, $57-71$.

Arlinghaus, R., Beardmoer, B., Riepe, C., Meyerhoff, J., Pagel, T., 2014. Species-specific preferences of German recreational anglers for freshwater fishing experiences, with emphasis on the intrinsic utilities of fish stocking and wild fishes. J. Fish Biol. 85, 1843-1867.

Arlinghaus, R., Alós, J., Krefoth, T., Laskowski, K.L., Monk, C.T., Nakayama, S., Schröder, A., 2016. Consumptive tourism causes timidity, rather than boldness, syndromes: a response to Geffroy. Trends Ecol. Evol. 31, 92-94.

Baruš, V., Oliva, O., 1995. Mihulovci Petromyzontes a Ryby Osteichthyes. Fauna ČR a SR [Lampreys and Fish. Fauna of Czechia and Slovakia]. Academia, Prague (Only in Czech).

Beukema, J.J., 1970. Acquired hook-avoidance in the pike Esox lucius L. fished with artificial and natural baits. J. Fish Biol. 2, 155-160.

Blabolil, P., Boukal, D.S., Ricard, D., Kubečka, J., Říha, M., Vašek, M., et al., 2017. Optimal gillnet sampling design for the estimation of fish community indicators in heterogeneous freshwater ecosystems. Ecol. Indicat. 77, 368-376.

Boulêtreau, S., Cucherousset, J., Villéger, S., Masson, R., Santoul, F., 2011. Colossal aggregations of giant alien freshwater fish as a potential biogeochemical hotspot. PLoS One 6, e25732.

Boulêtreau, S., Santoul, F., 2016. The end of the mythical giant catfish. Ecosphere 7, e01606.

Boulêtreau, S., Verdeyroux, P., Lorthiois, E., Azémar, F., Compin, A., Santoul, F., 2016. Do you eat or not? Predation behaviour of European catfish (Silurus glanis) toward live bait on a hook. Open Fish Sci. J. 9, 8-14.

Boulêtreau, S., Gaillagot, A., Carry, L., Tétard, S., De Oliveira, E., Santoul, F., 2018. Adult Atlantic salmon have a new freshwater predator. PLoS One 13, e0196046.

Britton, J.R., Pegg, J., Sedgwick, R., Page, R., 2007. Using mark-recapture to estimate catch rates and growth of the European catfish Silurus glanis in a recreational fishery. Fish. Manag. Ecol. 14, 263-268.

Britton, J.R., Cucherousset, J., Davies, G.D., Godard, M.J., Copp, G.H., 2010a. Non-native fishes and climate change: predicting species responses to warming temperatures in a temperate region. Freshw. Biol. 55, 1130-1141.

Britton, J.R., Davies, G.D., Brazier, M., 2010b. Towards the successful control of the invasive Pseudorasbora parva in the UK. Biol. Invasions 12, 125-131.

Britton, J.R., Gozlan, R.E., Copp, G.H., 2011. Managing non native fish in the environment. Fish Fish. 12, 256-274.

Cadrin, S.X., Pastoors, M.A., 2008. Precautionary harvest policies and the uncertainty paradox. Fish. Res. 94, 367-372.

Cardinale, M., Bartolino, V., Svedäng, H., Sundelöf, A., Poulsen, R.T., Casini, M., 2015. A centurial development of the North Sea fish megafauna as reflected by the historical Swedish longlining fisheries. Fish Fish. 16, 522-533.

Carol, J., Zamora, L., García-Berthou, E., 2007. Preliminary telemetry data on the movement patterns and habitat use of European catfish (Silurus glanis) in a reservoir of the River Ebro, Spain. Ecol. Freshw. Fish 16, 450-456.

Carol, J., Benejam, L., Benito, J., Garcia-Berthou, E., 2009. Growth and diet of European catfish (Silurus glanis) in early and late invasion stages. Fundamental and Applied Limnology/Archiv für Hydrobiologie 174, 317-328.

CEN, 2015. Water Quality _ Sampling of Fish with Multimesh Gillnets. European Committee for Standardization, Brussels EN 14757.

CFU, 2017. Fishing Regulations of the Czech Fishing Union. https://www.rybsvaz.cz/? page $=$ rybarsky_rad\&lang $=$ cz\&fromIDS $=$ \&rybarsky_rad_rok $=2017$.

Copp, G.H., Moffatt, L., Wesley, K.J., 2007. Is European catfish Silurus glanis really be coming more abundant in the River Thames? Aquat. Invasions 2, 113-116.

Copp, G.H., Britton, R., Cucherousset, J., García-Berthou, E., Kirk, R., Beeler, E., Skaténas, S., 2009. Voracious invader or benign feline? A review of the environmental biology of European catfish Silurus glanis in its native and introduced ranges. Fish Fish. 10, $252-282$.

Copp, G.H., Godard, M.J., Russell, I.C., Peeler, E.J., Gherardi, F., Tricarico, E., et al., 2014. A preliminary evaluation of the European nonnative species in aquaculture risk assessment scheme (ENSARS) applied to species listed on annex IV of the EU alien species regulation. Fish. Manag. Ecol. https://doi.org/10.1111/fme.12076.

Cucherousset, J., Boulêtreau, S., Azémar, F., Compin, A., Guillaume, M., 2012. "Freshwater Killer Whales": beaching behavior of an alien fish to hunt land birds. PLoS One 7, e50840.

Cucherousset, J., Horký, P., Slavík, O., Ovidio, M., Arlinghaus, R., Bouletreau, S., et al., 2018. Ecology, behaviour and management of the European catfish. Rev. Fish Biol. Fish. 28, 177-190.

Cunico, A.M., Vitule, J.R.S., 2014. First records of the European catfish, Silurus glanis linnaeus, 1758 in the americas (Brazil). BioInvasions Records 3 (2), 117-122.

Dudgeon, D., Arthington, A.H., Gessner, M.O., Kawabata, Z.I., Knowler, D.J., Léveque, C. et al., 2006. Freshwater biodiversity: importance, threats, status and conservation challenges. Biol. Rev. Camb. Philos. Soc. 81, 163-182.

FAO, 2018. Fishery and Aquaculture Statistics. Global Capture Production 1950-2016 (FishstatJ). In: FAO Fisheries and Aquaculture Department [online], Rome. Updated 2018. www.fao.org/fishery/statistics/software/fishstatj/en.

Fernö, A., Huse, I., 1983. The effect of experience on the behaviour of cod (Gadus morhua L.) towards a baited hook. Fish. Res. 2, 19-28.

Ferretti, F., Worm, B., Britten, G.L., Heithaus, M.R., Lotze, H.K., 2010. Patterns and ecosystem consequences of shark declines in the ocean. Ecol. Lett. 13, 1055-1071.

Frank, K.T., Petrie, B., Choi, J.S., Leggett, W.C., 2005. Trophic cascades in a formerly coddominated ecosystem. Science 308, 1621-1623.

Guillerault, N., Delmotte, S., Bouletreau, S., Lauzeral, C., Poulet, N., Santoul, F., 2015 Does the non-native European catfish Silurus glanis threaten French river fish populations? Freshw. Biol. 60, 922-928.

Hunt, L., 2005. Recreational fishing site choice models: insights and future opportunities. Hum. Dimens. Wildl. 10, 153-172.

Hutchings, J.A., Myers, R.A., 1994. What can be learned from the collapse of a renewable resource? Atlantic cod, Gadus morhua, of Newfoundland and Labrador. Can. J. Fish. Aquat. Sci. 51, 2126-2146.

Hutt, C.P., Hunt, K.M., Schlechte, J.W., Buckmeier, D.L., 2013. Effects of catfish angler catch-related attitudes on fishing trip preferences. N. Am. J. Fish. Manag. 33, 965-976.

Johnston, F.D., Arlinghaus, R., Dieckman, U., 2010. Diversity and complexity of angler behaviour drive socially optimal input and output regulations in a bioeconomic recreational-fisheries model. Can. J. Fish. Aquat. Sci. 60, 1507-1531.

Jørgensen, T., 1990. Long-term changes in age at sexual maturity of Northeast Arctic cod (Gadus morhua L.). Journal du Conseil International pour l'Exploration de la Mer 46, 235-248.

Jørgensen, C., Enberg, K., Dunlop, E.S., Arlinghaus, R., Boukal, B., Brander, K., et al., 2007. Managing evolving fish stocks. Science 318, 1247-1248.

Kennedy, T.A., Naeem, S., Howe, K.M., Knops, J.M.H., Tilman, D., Reich, P., 2002. Biodiversity as a barrier to ecological invasion. Nature 417, 636-638.

Last, P.R., White, W.T., Gledhill, D.C., Hobday, A.J., Brown, R., Edgar, G.J., Pecl, G., 2011. Long-term shifts in abundance and distribution of a temperate fish fauna: a response to climate change and fishing practices. Glob. Ecol. Biogeogr. 20, 58-72.

Laugen, A.T., Engelhard, G.H., Whitlock, R., Arlinghaus, R., Dankel, D.J., Dunlop, E.S. et al., 2014. Evolutionary impact assessment: accounting for evolutionary consequences of fishing in an ecosystem approach to fisheries management. Fish Fish. 15, 65-96.

Lewin, W.-C., Arlinghaus, R., Mehner, T., 2006. Documented and potential biological impacts of recreational fishing: insights for management and conservation. Rev. Fish. Sci. 14, 305-367.

Linhart, O., Štech, L., Švarc, J., Rodina, M., Audebert, J.P., Grecu, J., Billard, R., 2002. The culture of the European catfish, Silurus glanis, in the Czech Republic and in France. Aquat. Living Resour. 15, 139-144.

Matsumura, S., Arlinghaus, R., Dieckmann, U., 2011. Assessing evolutionary consequences of size-selective recreational fishing on multiple life-history traits, with an application to northern pike (Esox lucius). Evol. Ecol. 25, 711-735.

Morita, K., Tsuboi, J., 2004. Selectivity effects on wild white-spotted charr (Salvelinus 
leucomaenis) during a catch and release fishery. Fish. Res. 69, 229-238.

Mullon, C., Fréon, P., Cury, P., 2005. The dynamics of collapse in world fisheries. Fish Fish. 6, 111-120.

Myers, R.A., Baum, J.K., Shepherd, T.D., Powers, S.P., Peterson, C.H., 2007. Cascading effects of the loss of apex predatory sharks from a coastal ocean. Science 315 , $1846-1850$.

Pauly, D., 1995. Anecdotes and the shifting baseline syndrome of fisheries. Trends Ecol. Evol. 10, 430.

Post, J.R., Sullivan, M., Cox, S., Lester, N., Walters, C.J., Parkinson, E.A., Shuter, B.J., 2002. Canada's recreational fisheries: the invisible collapse? Fisheries 27, 6-17.

Prugh, R.L., Stone, C.J., Epps, C.W., Bean, W.T., Ripple, W.J., Laliberte, A.S., Brashares, J.S., 2009. The rise of the mesopredator. Bioscience 59, 779-791.

R Core Team, 2017. A Language and Environment for Statistical Computing. R Foundation for Statistical Computing, Vienna, Austria.

Ripple, W.J., Estes, J.A., Beschta, L.R., Wilmers, C.C., Ritchie, E.G., Hebblewhite, M., et al., 2014. Status and ecological effects of the world's largest carnivores. Science $343,1241484$.

Robson, D.S., Hegier, H.A., 1964. Sample size in petersen mark-recapture experiments. Trans. Am. Fish. Soc. 93, 215-226.

Robinson, L.A., Frid, C.L.J., 2003. Dynamic ecosystem models and the evaluation of ecosystem effects of fishing: can we make meaningful predictions. Aquat. Conserv. Mar. Freshw. Ecosyst. 13, 5-20.

Sakamoto, Y., Ishiguro, M., Kitagawa, G., 1986. Akaike Information Criterion Statistics. D. Reidel Publishing Company.

Schnabel, Z.E., 1938. To estimation of the total fish population of a lake. American Mathematical Monthly 45:348-352. 2005 In: Amstrup, S.C., McDonald, T.L., Manly, J.F. (Eds.), Handbook of Capture-Recapture Analysis, pp. 313 Princeton.

Seber, G.A.F., 1982. The Estimation of Animal Abundance and Related Parameters. Charles Griffin \& Co. Ltd, London, pp. 654.

Sienkiewicz, E., Gasiorowski, M., 2017. The diatom-inferred pH reconstructions for a naturally neutralized pit lake in south-west Poland using the Mining and the Combined pH training sets. Sci. Total Environ. 605-606, 75-87.

Sinclar, A.R.E., Mduma, S., Brashares, J.S., 2003. Patterns of predation in a diverse predator-prey system. Nature 425, 288-290.

Spurný, P., Mareš, J., Kopp, R., Grmela, J., Mareš, L., Malý, O., 2017. Socioekonomická Studie Sportovního Rybolovu V České Republice [Socio-Economic Aspects of Angling in the Czech Republic] 40pp Mendel University in Brno (Only in Czech).

Stone, R., 2007. The last of the Leviathans. Science 316, 1684-1688.

Syväranta, J., Cucherousset, J., Kopp, D., Crivelli, A., Céréghino, R., Santoul, F., 2010. Dietary breadth and trophic position of introduced European catfish Silurus glanis in the River Tarn (Garonne River basin), southwest France. Aquat. Biol. 8, 137-144.

Toresen, R., Østvedt, O.J., 2001. Norwegian spring-spawning herring (Clupea harengus) and climate throughout the twentieth century. In: Funk, F., Blackburn, J., Hay, D., Paul, A.J., Stephenson, R., Toresen, R., Witherell, D. (Eds.), University of Alaska Sea Grant College Program Report. Herring: Expectations for a New Millennium, pp. 279-284.

Vašek, M., Prchalová, M., Peterka, J., Ketelaars, H.A.M., Wagenvoort, A.J., Čech, M., et al., 2013. The utility of predatory fish in biomanipulation of deep reservoirs. Ecol. Eng. 52, 104-111.

Veit, R.R., Mcgowan, J.A., Ainley, D.G., Wahl, T.R., Pyle, P., 1997. Apex marine predator declines ninety percent in association with changing oceanic chmate. Glob. Chang. Biol. 3, 23-28.

Vejř́k, L., Vejř́́ková, I., Kočvara, L., Sajdlová, Z., Chung, S.H.T., Šmejkal, M., et al., 2017a. Thirty-year-old paradigm about unpalatable perch egg strands disclaimed by the freshwater top-predator, the European catfish (Silurus glanis). PLoS One 12 (1), e0169000.

Vejř́ik, L., Vejř́ková, I., Blabolil, P., Eloranta, A.P., Kočvara, L., Peterka, J., et al., 2017b. European catfish (Silurus glanis) as a freshwater apex predator drives ecosystem via its diet adaptability. Sci. Rep. 7, 15970.

Vejř́̌́ková, I., Vejř́ík, L., Syväranta, J., Kiljunen, M., Čech, M., Vašek, M., et al., 2016. Distribution of herbivorous fish is frozen by low temperature. Sci. Rep. 6, 39600. https://doi.org/10.1038/srep39600.

Venables, W.N., Ripley, B.D., 2002. Modern Applied Statistics with S, fourth ed. Springer.

Wysujack, K., Mehner, T., 2005. Can feeding of European catfish prevent cyprinids from reaching a size refuge? Ecol. Freshw. Fish 14, 87-95.

Wasserman, J.R., Alexander, M.E., Dalu, T., Ellender, B.L., Kaiser, H., Weyl, O.L., 2016. Using functional responses to quantify interaction effects among predators. Funct. Ecol. 30, 1988-1998.

Young, R.G., Hayes, J.W., 2004. Angling pressure and trout catchability: behavioral observations of Brown trout in two New Zealand backcountry rivers. N. Am. J. Fish. Manag. 24, 1203-1213. 